\title{
Commentary: Valve-sparing root replacement in patients with bicuspid versus tricuspid aortic valves: Is the comparison apples to apples?
}

\author{
Kevin L. Greason, MD
}

From the Department of Cardiovascular Surgery, Mayo Clinic, Rochester, Minn.

Disclosures: Author has nothing to disclose with regard to commercial support.

Received for publication Nov 10, 2018; accepted for publication Nov 12, 2018; available ahead of print Jan 14, 2019

Address for reprints: Kevin L. Greason, MD, Department of Cardiovascular Surgery, Mayo Clinic, Joseph 5-200, Rochester, MN 55905 (E-mail: greason.kevin@mayo.edu).

J Thorac Cardiovasc Surg 2019;158:12-3

$0022-5223 / \$ 36.00$

Copyright (c) 2018 by The American Association for Thoracic Surgery

https://doi.org/10.1016/j.jtcvs.2018.11.041

Readers of the Journal should find interest in this study about aortic-valve sparing root replacement for root aneurysm from the team at the Toronto General Hospital. ${ }^{1}$ The analysis focused on valve repair in 45 patients with bicuspid aortic valve anatomy. A control group included 288 patients with tricuspid aortic valve anatomy. The present series adds to the growing body of literature on valve-sparing root replacement in patients with bicuspid and tricuspid aortic valve anatomy.

The primary analysis was performed on a propensitymatched dataset in an attempt to mitigate known differences in patient characteristics between the bicuspid and tricuspid aortic valve groups (45 bicuspid valve patients to 135 tricuspid valve patients; 1:3 matching). Despite the matching, important clinical differences persisted in the prevalence of Marfan syndrome (bicuspid valve group 9\% vs tricuspid valve group $53 \% ; P<.001)$ and aortic regurgitation (bicuspid valve group $78 \%$ vs tricuspid valve group $61 \% ; P=.03)$.

Anatomic differences in the 2 valve types likely resulted in the use of different repair techniques between the groups. This included any cusp repaired (bicuspid valve group 79\% vs tricuspid valve group $45 \% ; P<.001$ ), any cusp plicated (bicuspid valve group $76 \%$ vs tricuspid valve group $35 \%$; $P<.001$ ), any cusp shorted by plication (bicuspid valve group $76 \%$ vs tricuspid valve group $35 \% ; P<.001$ ), and creation of neoaortic sinus (bicuspid valve group $46 \%$ vs tricuspid valve group $58 \% ; P=.007$ ).

In the bicuspid valve group, the median follow-up was 5.6 years (Interquartile range 3.3-9.6 years), which included echocardiography in $98 \%$ of patients without terminal events during the most recent 3 years. The authors report excellent 10-year outcomes: freedom from mortality was $100 \%$, cumulative incidence of moderate/severe aortic valve regurgitation was $6.5 \%$, cumulative incidence of repeat aortic valve operation was $4.2 \%$, and cumulative

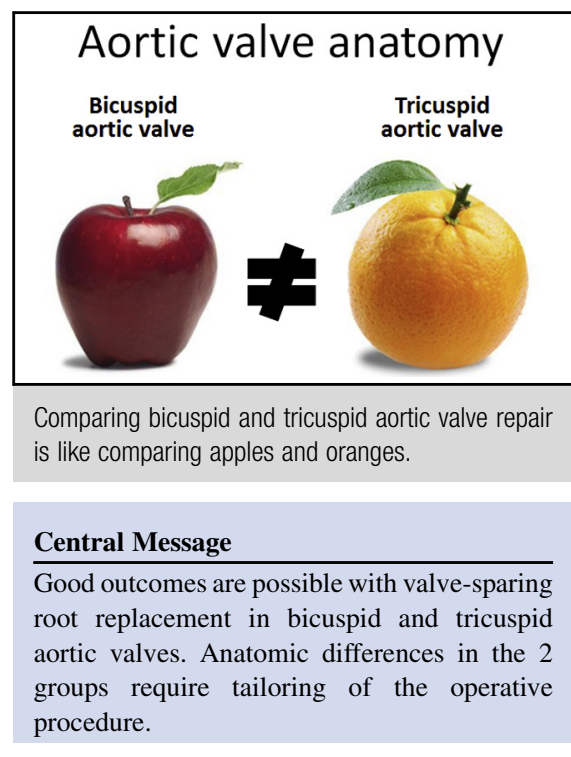

See Article page 1.

incidence of valve-related events was $20.5 \%$. These event rates were similar to those in the control group.

There are several important lessons to be learned from this study. First, it is clear that bicuspid and tricuspid valve patients are clinically and anatomically different. It is likely that no amount of statistical massage can compensate for the differences. Second, despite the differences, outcomes were excellent in both groups. And third, in the hands of these world-class surgeons, most patients with bicuspid aortic valve anatomy were not candidates for a valvesparing approach. In this series, only $7 \%$ of the patients with bicuspid aortic valve anatomy who received root replacement had a valve-sparing approach.

The present study supports the long-term durability of valve-sparing root replacement in a highly selected group of patients with bicuspid aortic valve anatomy. ${ }^{2}$ The recipe for success includes minimal valve calcification, no restricted cusp motion, no need for cusp patch augmentation or replacement, and anatomy otherwise conducive to valve reimplantation-an apparently uncommon confluence of findings. Valve-sparing root replacement is possible, but surgical judgment and experience are paramount to successful outcomes. 


\section{References}

1. Ouzoumian M, Feindel CM, Manlhiot C, David C, David TE. Valve-sparing root replacement in patients with bicuspid versus tricuspid aortic valves. J Thorac Cardiovasc Surg. 2019;158:1-9.
2. Bavaria JE, Desai N, Szeto WY, Komlo C, Rhode T, Wallen T, et al. Valvesparing root reimplantation and leaflet repair in a bicuspid aortic valve: comparison with the 3-cusp David procedure. J Thorac Cardiovasc Surg. 2015; 149:S22-8.

Access to The Journal of Thoracic and Cardiovascular Surgery Online is reserved for print subscribers!

Full-text access to The Journal of Thoracic and Cardiovascular Surgery Online is available for all print subscribers. To activate your individual online subscription, please visit The Journal of Thoracic and Cardiovascular Surgery Online, point your browser to http://www.mosby.com/jtcvs, follow the prompts to activate your online access, and follow the instructions. To activate your account, you will need your subscriber account number, which you can find on your mailing label (note: the number of digits in your subscriber account number varies from 6 to 10 ). See the example below in which the subscriber account number has been circled:

\section{Sample mailing label}

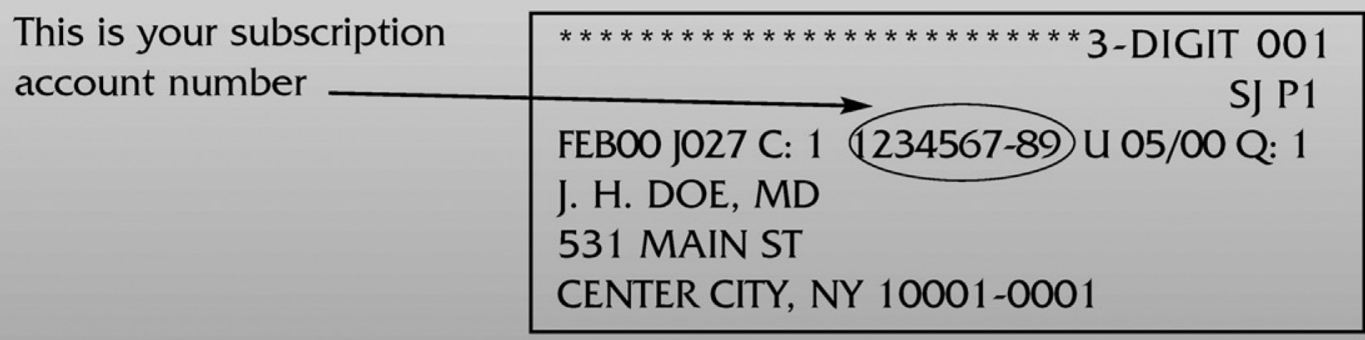

Personal subscriptions to The Journal of Thoracic and Cardiovascular Surgery Online are for individual use only and may not be transferred. Use of The Journal of Thoracic and Cardiovascular Surgery Online is subject to agreement to the terms and conditions as indicated online. 